\title{
An Empirical Evidence of the International Fisher Effect on the USD to CNY Exchange Rate
}

\author{
MSc. Jona Puci \\ MSc. Saimir Mansaku \\ Canadian Institute of Technology, Tirana, Albania \\ Email: j.puci@cit.edu.al/Email: saimir.mansaku@cit.edu.al
}

Doi:10.5901/ajis.2016.v5n1p249

\begin{abstract}
Because of the growth of financial globalization in the last decades, international parity relations have been widely considered owing to their significance and influence in investment decisions and international trades. This paper analyses the International Fisher Effect (IFE) considering United State Dollar (USD) and Chinese Yuan Renminbi (CNY) for the period 2002 2014/Q1. In order to reach this objective Augmented Dickey Fuller and Phillip Peron unit root tests are performed to check for stationary. Moreover, Engle - Granger and Johansen co - integration techniques are performed to identify long run relationships. Even if, IFE might not be successful to apply in daily currency transaction, its usefulness consists in its capability to illustrate the expected relation among exchange rates, interest rates and inflation. Further, this information is beneficial in searching export possibilities for countries and in assessing the price of foreign imports.
\end{abstract}

Keywords: IFE, USD, RMB, exchange rates, inflation and interest rates.

\section{Introduction}

The international Fisher Effect or IFE is an exchange-rate theory designed by the American economist Irving Fisher in the 1930 s which states that for any two countries an expected change in the future spot rate between two currencies leads to a difference in approximately equal amount but in the opposite direction between the two countries' nominal interest rates. This theory assumes the appreciation or depreciation of currency prices which are closely related to differences in nominal interest rates. Thus, the rational for IFE is that the currency of the country with higher nominal interest rate will depreciate against the other country's currency due to the increase in inflation rate in that country.

The main problem is if this theory works now when currencies are allowed to free float. Taking into consideration the numerous factors that affect predictions of nominal and exchange rates, we can say that IFE is generally unreliable in the short run. In the longer run, it has demonstrated a bit better relation between the financial indicators, but not by much. This model may be not applicable in daily currency trades, but its usefulness consists in showing the expected relation between exchange rates, inflation and interest rates.

The main purpose of this paper is to analyze in depth the International Fisher effect model with respect to the currencies of U.S. and China and the inflation rates of these two countries for the period from 2002 to 2014. The paper is organized as follows: The next section provides a literature review highlighting the reasons of deviations from IFE. The third part describes the methodology applied. The fourth part analyzes the data within the sample considered. The fifth section presents the empirical results of the study. The final part draws the conclusions with the main findings of this paper.

\section{Literature Review}

The Fisher's theory is considered as one of the most significant theory in macroeconomics. Fisher (1930) emphasized that the nominal exchange rate comprises an expected inflation rate plus an expected real rate. Numerous studies have tested the Fisher theory over the years. These studies have provided diverse results. Cumby and Obstfeld (1981) concluded that the IFE is not known as a good forecaster of short term changes in spot exchange rate. As stated by MacDonald and Murphy (1989) the results differ with time periods and across countries as well. The same result was emphasized by Hill (2004), where he stated that a connection among interest rate differentials and following variations in 
spot exchange rate seems to exist in the long run, but with significant deviations in the short term.

The test performed by Thomas (1985) of the Fisher hypothesis by checking outcomes of future contracts of currencies with higher interest rate that included discounts and selling futures on currencies with low interest rate that included premiums. Contradictory to the Fisher theory the research found that about $60 \%$ of the agreements generated by this strategy were successful. In average terms the profit was higher than the loss. In that case where Fisher's theory holds the low interest rate currencies should appreciate whereas the high interest rate currencies should depreciate. Hakkio (1986) concluded that the relation among exchange rates and interest rates differentials was not perfect even in the long run. According to Khalwaty (2000), the inconsistency may be clarified by the fact that there are a lot of factors that could cause exchange rates oscillation. This comprises foreign exchange demand and supply, rising inflation, monetary policy, balance of payments problems and national income.

A research of Madura and Nosari (1984) followed a strategy by borrowing currency with the lowest interest rates and invested in the currency with the highest interest rate. At the end of the period, it was concluded that the change between the cost of borrowing and the return on the investment was positive. This was contradictory to the Fisher theory. A recent study of Eno and Suti (2009), tested the IFE for four foreign countries, the US, UK, Singapore and Japan, considering Indonesia as the home country. The study was extended over the period $2003-2008$ using quarterly and yearly data for the interest rate differentials and changes in exchange rates. Regression outcome indicated that interest rate differentials were positively affecting changes for exchange rate for the UK, Singapore and the US relative to that of Indonesia. On the other side, interest rate differentials, have negatively affected changes in exchange rates for Japan.

\section{Methodology}

The data necessary for this research include monthly Consumer Price Index value and monthly interest rates of US and China. The period covered is from January 2002 until December 2014, monthly data, a total of 156 observations. The issue that this research aims is whether nominal short - term interest rates affect exchange rates. First, ADF and PP unit root tests of level and first difference are performed to check if the time series are stationary or not. ADF is a parametric test, meaning that is more powerful than nonparametric tests and performs better especially if the sample is small. The variations between these two tests are not highly important. The overall consideration is that PP is very similar to ADF in terms of the results.

Hypothesis:

- $H_{0}$ : If critical value < t-statistic (in absolute value), unit root exist and we fail to reject the null hypothesis - the data are non - stationary

- $H_{1}$ : If critical value > t-statistic (in absolute value), unit root doesn't exist, so we reject the null hypothesis - the data are stationary

If the null Hypothesis is accepted, it is supposed that there is a unit root and the series will then be tested in the first difference.

Secondly, co-integration technics, Engle - Granger and Johansen, are performed to check for long run relationships between non stationary variables. The primary reason for using co- integration techniques is to evade "spurious" regression results. If two time series, or more than two, are co- integrated, it shows that in the long run they have a relation which in the short run might deviate from its equilibrium, but in the long run will always return to. $\mathrm{A}$ necessary condition for the co - integration technic is that the order of integration in the long run of all the elements must be the same and the time series should be non - stationary in levels. The order of integration is the number of times the data should be differenced in order to become stationary. Integrated of order $n$ are those series that have become stationary when differenced $n$ times.

Hypothesis:

Null hypothesis: $\quad$ No co - integration

Alternative hypothesis: Co - integration

Johansen's methodology major advantage against Engle-Granger is that it can assess the co-integration between more than two variables.

\section{Data Analysis}

The data cover monthly observations of the interest rates and inflation rates for the two countries and also the exchange rates of the USD to CNY. The total sample covers the period from January 2002 to December 2014, amounting to 156 
observations in total.

The central bank of the Republic of China is called "The People's Bank of China "or PBOC. This bank has the complete autonomy with respect of monetary instruments. The decisions related to interest rates are taken by the People's Bank of China Monetary Policy Committee. The PBC controls two benchmark interest rates: a lending rate and an annual deposit rate. Therefore, it has a lot of impact over the rates paid in the market for loans and mortgages and the interest paid on savings.

The PBOC has cut interest rates at the end of February 2002, for the first time after two and a half years. The last cut before that was in June 2009. According to a PBOC spokesman, these cuts followed a sustained decrease in economic growth and lower consumer prices over the last moths of that time. The move of PBOC intended to overcome the impact of slowing world economy on China, to support industry by decreasing the one-year lending rate from 5.85\% to $5.31 \%$ and to encourage the households to spend and halt deflation by cutting one-year deposit rate and creating a firmer market.

On October 29, 2004 the benchmark one - year Yuan lending rate went up to 5.58\% from staying stable since February 2002 at $5.31 \%$. The banks were allowed to charge borrowers above the benchmark, but they could offers rates on loans at little as $90 \%$ of that benchmark. The move, intended to curb inflation and prevent overheating in the economy, is the latest of several efforts by the Chinese government this year to reduce the rate of growth, but is the first use of interest rates, the most fundamental monetary policy tool at a central bank's disposal. In February 2006, PBOC gave permission to commercial banks to trade interest rate swaps.

On April 27, 2006, as it is observed in the Graph 1, the unexpected increase in one-year lending rate to $5.85 \%$ from 5.58\% signaled an effort of Beijing's policies to restrain the booming investment and credit growth (loan expansion) in order to support sustainable development of the economy. The continuous increases in the lending rate until late 2008 aimed to further strength the macro control and keep economy to grow in a healthy manner. During October - December 2008, PBOC made a series of rate cuts in order to steer the economy through the global crisis. The benchmark one-year lending rate dropped to $5.31 \%$ by December 2008 .

In July 2011, the one-year benchmark lending rate was raised by 25 bps to $6.56 \%$. The main reason was to curb the rising inflation rate which was, as of May 2011 , at $5.5 \%$ on a yearly scale well above the target inflation of $4 \%$. As it is shown on the graph, in June 08, 2012 the official lending rate was cut for the first time since 2008 after a series of rises in the in-between years to $6.31 \%$ and the one year deposit rate to $3.25 \%$. During this month the manufacturing sector weakened. Referring to the survey of purchasing managers conducted by Chinese government, there was a sharp fall in new export orders as the Chinese economy is affected a lot by changes in other parts of the world.

While the adjustments of floating range of deposit and lending rate were a strong signal to help the economy to boost in a short term, it was also an important step toward liberalization of interest rates with respect to longer-term repercussions (impact). It gave banks the freedom to offer rates on new loans for as $80 \%$ of the benchmark, an additional $10 \%$ points from previous floor and set deposit rates as high as $110 \%$ of official rates. One month later, in July 2012 PBC cut further its one-year lending rate by 0.31 percentage point to $6 \%$ when it remained till end of November 2014. It also brought down one - year benchmark deposit rates by 0.25 percentage points to $3 \%$. The floor for lending rates dropped to $70 \%$ of benchmark rates from previous $80 \%$, but the ceiling on deposit rates unchanged. The consecutive cuts increased the returns for households and created more competition between banks. These cuts were caused concerning the slowdown in economic growth of China.

On July 19, 2013, the PBOC scraps the floor on bank lending rates and frees up bank discount rates. It does not change the ceiling on bank deposit rates. The last change after this period was on November 21, 2014. On that day, PBOC announced that it was reducing its benchmark one - year lending rate by 40 basis points from $6 \%$ to $5.6 \%$. Additionally, it also cut one-year benchmark deposit rates by 25 basis points to $25 \%$. Both changes were effective one day after on November 22, 2014 and they surprised markets after a stable interest rate of $6 \%$ for more than two years.

As shown in the Graph 1, in November 2002 U.S. central bank, so call Federal Reserve (Fed) slashed lending rates to $1.25 \%$ in order to push the sluggish U.S. economy. It was the first rate cut of the year, a half point where most economists expected a quarter-percentage-point cut. On June 25, 2003 the Federal Reserve cut further its key short-term interest rate by a quarter to $1 \%$ and remained at this level for a year. However, the cut was smaller than some market participants expected, causing a selloff in stocks and bonds. The interest rate hike cycle began in June 2004, being raised to $1.25 \%$, followed then by 17 rate hike reaching a high of $5.25 \%$ in June 2006 . During this period, the US economy experienced a good rate of GDP growth with an average of 3.3\%. The Fed, through implementation of monetary policies sought to ensure the maximum employment, moderate long - term interest rate while maintaining a healthy inflation rate. Hence, it was due to continuously strong employment and achievement of targeted inflation rate 
that prompted the Fed to keep increasing interest rates within this period. To date, unemployment is at $5.1 \%$ with core inflation at $1.3 \%$.

Though the full employment has been reached, the Fed's own inflation target is still some ways to go. After June 2006, the interest rates were left unchanged at $5.25 \%$ for more than a year. However, at the end of 2007the difficulties in refinancing sub-prime mortgages, the fall in housing prices became a matter of concern with regard to financial markets. In order to easy these conditions, the interest rates were reduced to $4.75 \%$ followed by additional cuts throughout 2008 . Beginning from December 2008 the Federal Reserve adopted a very low interest rate policy, with interest rates set at $0.25 \%$ at the height of the Global Financial Crisis and kept them there until the end of 2015 in an effort to encourage the economy.

Graph 1: Interest Rates of USD and CNY

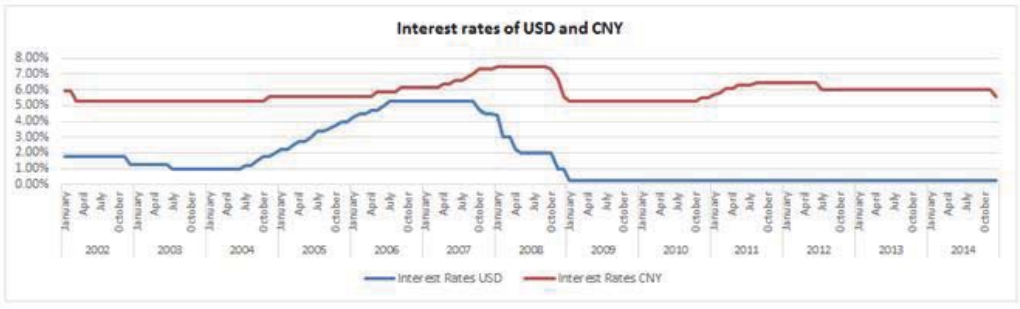

Graph 2: Exchange Rates USD/CNY

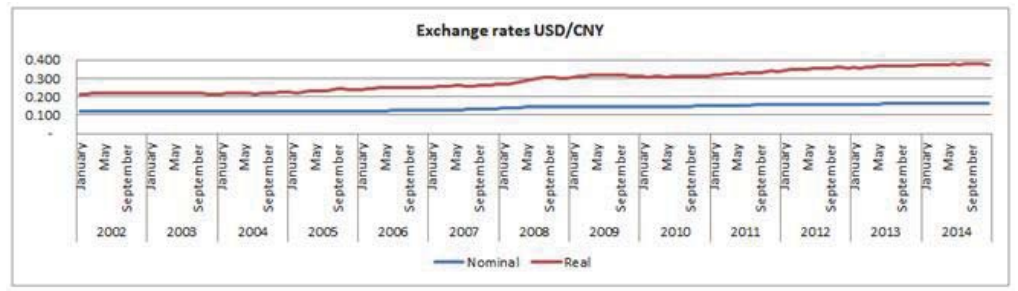

Referring to the Republic of China, for the most time of its early history, the exchange rate of the Renminbi (RMB) was pegged to the U.S. dollar at $¥ 2.46$ per USD. This rate did not reflect purchasing power parities and it had a small role in China's economy. During the 1970s, the RMB was revalued until it became $¥ 1.50$ per USD in 1980. When China's economy gradually opened in 1980s, the RMB was devalued in order to improve the competitiveness of Chinese exports so its USD to RMB exchange rate declined from $¥ 1.50$ in 1980 to $¥ 8.62$ by 1994 . During the latter half of the 1990s, the Chinese government improved current account balance and pegged the RMB to USD at US Dollar at approximately 8.3 CNY to 1 USD from 1997 until 2005.

As it is observed in the Graph 2, on July 21, 2005, the peg against US dollar was lifted and as a managed float, the value of RMB was determined by a basket of currencies, mainly dominated by US dollar, the euro, the Japanese yen and the Korean won, with a smaller proportion made up of the British pound, Thai baht, Russian ruble, Australian dollar, Canadian dollar and Singapore dollar. The RMB was re-evaluated to $¥ 8.11$ per USD, representing a far smaller appreciation that had been called for by the United States and other trading partners. In the following three years, under the intense pressure of Washington, China took small steps to strengthen its currency and further gentle appreciation against US dollar occurred. On April 10, 2008, RMB was traded at $¥ 6.9920$ per USD, the first time in more than a decade that the value of a dollar was less than seven Yuan. Since mid-2008, the RMB has been held stable as the Chinese government considers how best to respond to the global economic crisis. As the global financial crisis intensified in July 2008 and the demand for Chinese products dropped, the China halted the Yuan appreciation to the dollar. After that, the RMB had risen to nearly $¥ 6.8$ per USD by the end of October 2008.In June 2010, following the start of the Greek government-debt crisis, the temporary dollar peg was again replaced by the flexible mechanism and China resumed its policy of moving up the Yuan. However, the Chinese currency was only allowed by the PBOC to appreciate gradually against the US dollar. The markets worldwide surged after PBOC announcement while the RMB had risen to its highest 
level since 2005. After that, the RMB depreciated against U.S. dollar between May and July 2012, when it fell around 2\%, since the China moved away from currency peg. In February 2014, the RMB was worth 6.12 to the U.S. dollar when a year ago it was 6.22 U.S. dollar. So the Yuan continued to appreciate as the market expected and as the government of China promised. On March 2014, RMB weakened $0.5 \%$ to $¥ 6.23$ per USD. So far, the RMB fell $2.9 \%$ against the USD and it continued for several months.

When we talk about the inflation, this refers mostly to the rate of inflation based on the consumer price index or $\mathrm{CPI}$ for short. In order to calculate the CPI, we primarily use the basket of goods, which is relatively a fixed set of consumer products and services valued to track the inflation in a specific country. The goods and services in the basket are adjusted periodically due to changes in consumer habits. Hence, the Producer Price Index or PPI, a sister report to the $\mathrm{CPI}$, measures the average changes in prices at the domestic factory doors for their outputs and inflation pressures before they reach to the consumer.

In U.S, monthly inflation rates are calculated using 12-month Consumer Price Index published monthly by the Bureau of Labor Statistics (BLS). Core inflation is a measure of inflation that leaves out several items, such as food and energy that encounters unstable price movement. It is a critical data observed by the Fed's Federal Open Market Committee (FOMC) as it helps in determining the interest rate benchmark. For example, to calculate the inflation rate for January 2014, take its CPI of "233.92" and subtract from it last year's January 2013 CPI of "230.28." The result is "3.64." Divide this number by the January $2013 \mathrm{CPI}$ and then multiply that by 100 and add a \% sign. The result is January 2014's annual inflation rate of $1.58 \%$. Since figures below are 12-month periods, we look to the December of each year to find annual inflation rates. For example, the rate of inflation in 2014 was $0.8 \%$.

Graph 3: Inflation Rate of US and China

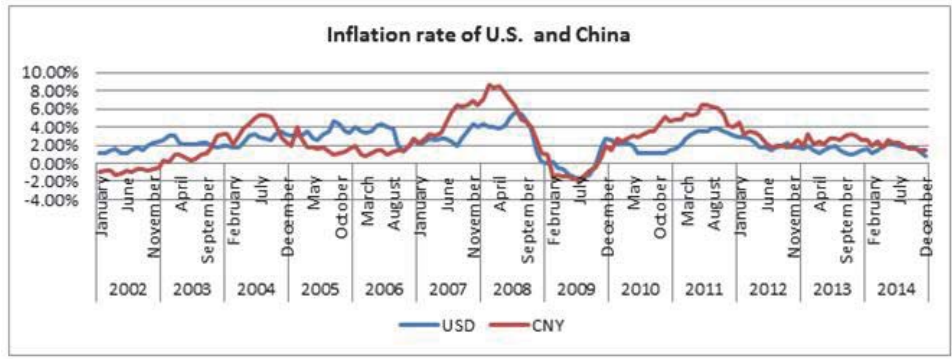

In China, inflation has followed a cyclical pattern. During 2002, China experienced mild inflation, even deflation, but beginning from 2003, the inflation rates have increased. In December 2007, the inflation rate rose at $6.5 \%$ with price rises reaching nearly $20 \%$ for agricultural commodities. According to China's National Bureau of Statistics, in February 2008, the consumer prices surged to $8.7 \%$ from $7.1 \%$ in January of that year, the fastest pace of increase in more than 11 years. Food costs were the biggest contributor to these prices hikes with up 23.3\% from February 2007. Moreover, the producer prices were up 6.6\% from February 2007. In January 2009, inflation fell $1 \%$ from $1.2 \%$ in December 2008, the ninth consecutive monthly drop, well below of $8.7 \%$ reached in February of one year earlier. According to the National Bureau of Statistics, the producer prices slowed 3.3\%, the biggest decline since 2002. During 2010, the consumer prices were up over the previous year, due to the increase of food and energy costs. In September 2010, CPI recorded 3.6\%, just $0.1 \%$ month over month. Food prices rose 1.4\%, recording the largest increase since October 2008, while energy prices rose $3.8 \%$.

Moreover, the so-called core CPI rose at a $0.8 \%$ annual rate, down slightly from $0.9 \%$ in August 2010. Compared to December 2010, inflation fell slightly to $4.2 \%$ in November 2011. This figure marked a continuous straight decline since a peak of $6.5 \%$ in July 2011, bolstering the expectations that prices were on a solid downtrend. It also calmed the investors' concerns about a sharp slowdown in China. Regarding the food prices, an important source of inflationary pressure in China, the data reported shown a rise of $11.9 \%$ in October 2011 compared to a year earlier, the smallest increase since May 2011. From December 2012 until December 2013 the CPI rose 2.5\% year on year, down from 3.2 in October 2013. For the full year of 2014 , consumer prices increased by $2.0 \%$ in average, a good figure within the government's goal to keep inflation below 3.5\%.

After the end of World War II, the United States has experienced continuous inflation, one of the most 
differentiating characteristics of the American economy. As it is shown on the Graph 3, for the years 2002-2008, the rates have been $2.4 \%, 1.9 \%, 3.3 \%, 3.4 \%, 2.5 \%, 4.1 \%$ and $0.1 \%$ respectively. Much of the upward pressure on prices during $2002,2004,2005,2006,2007$, and the first half of 2008 (until 5.6\% in July 2008) have come from high energy prices. Likewise, the decline in the inflation rate during 2003 was due to a large fall in energy prices.

Higher prices for both energy and food in 2007 pushed inflation up by $4.1 \%$, sharply from a $2.5 \%$ increase in 2006. This has been the largest increase since $6.1 \%$ jump in prices in 1990. Energy costs rose by 17.4 percent while food costs rose by 4.9 percent. Outside of food and energy, the prices remained tame and core inflation raised more moderate by 2.4 percent for all of 2007, down slightly from a 2.6 percent increase in 2006 . It was the smallest record since $2.2 \%$ rise in 2005. Meanwhile, the flat industrial output in December showed more significant evidence of slowdown in the U.S. economy. Workers' wages failed to keep up with the increased inflation. After adjusting for inflation, the average weekly earnings dropped by $0.9 \%$ in 2007, the biggest setbacks for that time since a $1.5 \%$ fall in 2005.

The rate in December 2008 recorded at $0.1 \%$, the cost of living dropped as a result of consumer prices fall. The energy index was driven down $8.3 \%$ which led to the decline of CPI by $0.7 \%$, the most watched gauge for inflation. Core inflation rose $1.08 \%$ on a yearly basis, being within 1\%-2\% comfort zone of Federal Reserve. U.S. government reported that US inflation increased 2.7 percent in 2009. In November 2009, US inflation returned to positive value for the first time since February of that year, the Americans paid more for energy and as a result the cost of living was brought up from the prior month. Comparing 2009 to 2008 when inflation came in at 0.1 percent, higher prices of gasoline greatly affected to this difference.

US annual inflation increased 1.5\% in 2013, marking the smallest amount since 2010's matching of 1.5\% increase. Comparing the two previous years, the inflation rate in December 2011 was leapt 3\% and drove ahead 1.7\% in 2012. During 2013, the gasoline prices fell 1.0\% from 1.7\% in 2012 and although the food prices went up 1.1\%, that was tamer than prior year of $1.8 \%$.

In 2014 US inflation rose $0.8 \%$, the smallest change for a calendar year since 2008 , when it increased $0.1 \%$. It included the $1.1 \%$ rise in February, the gain of $1.5 \%$ in March following the increase of $2 \%$ in April and the advance of 2.1\% in May and June. During the August, September and October 2014 the inflation rate was at 1.7\% and in November climbed 1.3\%. In China, the inflation rate is periodically reported by the National Bureau of Statistics of China. Regarding the CPI basket, the most important components are Food which account for $31.8 \%$ and Residence for $17.2 \%$ of total weight. Education, Recreation and Culture Articles, Transportation and Communication, Healthcare and Personal Articles and some other components account for the remaining 51\%.According to the National Bureau of Statistics, the CPI basket is reviewed every five years based on household surveys in order to mirror new spending patterns and economic development as a whole.

\section{Analysis of the Results}

\subsection{Stationary tests}

Table 1: Stationary tests

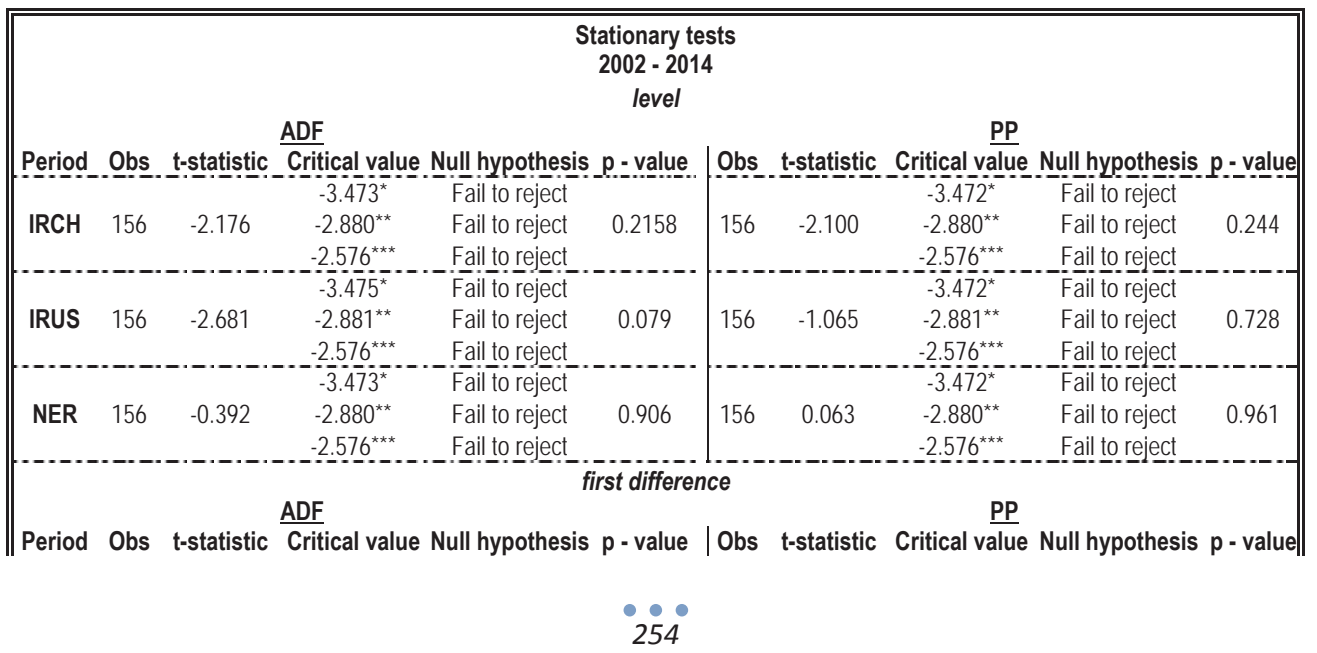




\begin{tabular}{|c|c|c|c|c|c|c|c|c|c|c|}
\hline IRCH & 153 & -7.594 & $\begin{array}{l}-3.473^{\star} \\
-2.880^{\star \star} \\
-2.576^{\star \star \star}\end{array}$ & $\begin{array}{l}\text { Reject } \\
\text { Reject } \\
\text { Reject }\end{array}$ & 0.000 & 154 & -7.587 & $\begin{array}{l}-3.472^{\star} \\
-2.880^{\star \star} \\
-2.576^{\star \star \star}\end{array}$ & $\begin{array}{l}\text { Reject } \\
\text { Reject } \\
\text { Reject }\end{array}$ & 0.000 \\
\hline & & & $-3.474^{*}$ & Reject & & & & $-3.473^{*}$ & Reject & \\
\hline IRUS & 152 & -3.900 & $\begin{array}{l}-2.880^{* *} \\
-2.576^{\star * *}\end{array}$ & $\begin{array}{l}\text { Reject } \\
\text { Reject }\end{array}$ & 0.002 & 154 & -11.855 & $\begin{array}{c}-2.881^{\star *} \\
-2.576^{\star \star \star}\end{array}$ & $\begin{array}{l}\text { Reject } \\
\text { Reject }\end{array}$ & 0.000 \\
\hline & & & $-3.473^{\star}$ & Reject & & & & $-3.473^{*}$ & Reject & \\
\hline NER & 152 & -3.611 & $\begin{array}{c}-2.881^{* *} \\
-2.576^{\star * *}\end{array}$ & $\begin{array}{l}\text { Reject } \\
\text { Reject }\end{array}$ & 0.006 & 154 & -8.472 & $\begin{array}{c}-2.880^{\star \star} \\
-2.576^{\star \star \star}\end{array}$ & $\begin{array}{l}\text { Reject } \\
\text { Reject }\end{array}$ & 0.000 \\
\hline
\end{tabular}

As shown in the Table 1 the results of the econometric analysis performed using EViews7 software are presented. The model is with intercept and trend, and the ADF and PP statistics are comparatively described at $1 \%, 5 \%$ and $10 \%$ levels of significance. The results shows that ADF statistic for China's Interest Rate, US's Interest Rate and Nominal Exchange Rate are within the acceptance area for all the series tested at $5 \%$ and $10 \%$ levels of significance. Meaning that, unit root exist and the Null hypothesis cannot be rejected, therefore, these series rates are found to be non-stationary on levels. After taking the first difference of the data the Null hypothesis is rejected at $1 \%, 5 \%$ and $10 \%$ for all the series and the data are found to be stationary. According to PP test the outcomes are the same as the results from ADF test. After differencing the data the series become stationary leading so to the same result as ADF test.

\subsection{Co-integration tests}

Table 2 presents the outcomes after having applied co-integration tests. Nominal exchange rates and the interest rates of China and US are tested to determine their order of integration. For the whole sample (2002 - 2014) it is possible to apply the co-integration tests because the data are non - stationary on level and they have the same order of integration. EngleGranger co-integration test is unable to reject the Null hypothesis for the period under investigation. Meaning that the residuals are non - stationary and there is no co-integration among the variables. In contrary of Engle - Granger, Johansen test is able to reject the Null hypothesis for the period taken into account at $1 \%$ confidence level. Both tests the Trace test and the Maximum Eigenvalue, lead to the same result, that there is no co-integration among the variables or they don't move together in the long run, indicating that according to Johansen technique interest rates do not affect nominal exchange rates at $5 \%$ and $10 \%$.

Table 2: Co - integration tests

\begin{tabular}{|c|c|c|c|c|c|c|c|c|c|c|c|c|c|c|c|}
\hline \multicolumn{4}{|c|}{$\begin{array}{l}\text { Integration Order - I(n) based on the } \\
\text { ADF }\end{array}$} & \multicolumn{4}{|c|}{ Engle - Granger } & \multicolumn{8}{|c|}{ Johansen } \\
\hline & $N E R$ & $\mathrm{IRCH}$ & IRUS & $\begin{array}{c}t- \\
\text { statistic }\end{array}$ & $\begin{array}{l}\text { Critical } \\
\text { values }\end{array}$ & $\begin{array}{l}\text { Null } \\
\text { hypoth } \\
\text { esis }\end{array}$ & $\begin{array}{c}p- \\
\text { value }\end{array}$ & $\begin{array}{l}\text { No. of } \\
C E(s)\end{array}$ & $\begin{array}{c}\text { Trace } \\
\text { statisti } \\
c\end{array}$ & $\begin{array}{c}\text { Critical } \\
\text { value at } \\
0.05\end{array}$ & $\begin{array}{cc}P- & \text { Null } \\
\text { valu } & \text { hypoth } \\
e & \text { esis }\end{array}$ & $\begin{array}{l}\text { Max- } \\
\text { Eigen } \\
\text { statistic }\end{array}$ & $\begin{array}{l}\text { Critical } \\
\text { value } \\
\text { at } 0.05\end{array}$ & $\begin{array}{c}P- \\
\text { value }\end{array}$ & $\begin{array}{c}\text { Null } \\
\text { hypothe } \\
\text { sis }\end{array}$ \\
\hline \multirow{3}{*}{2002 - 2014} & $\mathrm{I}(1)^{*}$ & $\mathrm{I}(1)^{*}$ & $\mathrm{I}(1)^{*}$ & & -3.742 & $\begin{array}{l}\text { Fail to } \\
\text { reject }\end{array}$ & & None & 40.643 & 29.797 & 02 Reject & 31.293 & 21.131 & 0.001 & Reject \\
\hline & $I(1)^{\star *}$ & $\mathrm{I}(1)^{\star *}$ & $\mathrm{I}(1)^{\star *}$ & -1.421 & -2.880 & $\begin{array}{l}\text { Fail to } \\
\text { reject }\end{array}$ & 0.571 & $\begin{array}{c}\text { At } \\
\text { most } 1\end{array}$ & 9.351 & 15.494 & $\begin{array}{lr}0.3 & \text { Fail to } \\
34 & \text { reject }\end{array}$ & 9.326 & 14.264 & 0.261 & $\begin{array}{l}\text { Fail to } \\
\text { reject }\end{array}$ \\
\hline & $I(1)^{\star * *}$ & $I(1)^{\star * *}$ & $\mathrm{I}(1)^{\star \star *}$ & & -2.576 & $\begin{array}{l}\text { Fail to } \\
\text { reject }\end{array}$ & & $\begin{array}{c}\text { At } \\
\text { most } 2\end{array}$ & 0.030 & 3.841 & $\begin{array}{lr}0.8 & \text { Fail to } \\
61 & \text { reject }\end{array}$ & 0.031 & 3.841 & 0.861 & $\begin{array}{l}\text { Fail to } \\
\text { reject }\end{array}$ \\
\hline
\end{tabular}

\section{Conclusions}

The main objective of this paper was to define the validity of the IFE for the USD and CNY exchange rates from 2002 to 2014. Augmented Dickey Fuller and Phillip Peron unit root tests have been used to check the stationary of the time series and the results of these tests led to the application of co-integration techniques such as Engle-Granger and Johansen. According to Johansen, we found evidence in favor of the theory only at $1 \%$ confidence level.

Nowadays interest rates don't change by the same magnitude as in the past, so the IFE isn't as credible as it once was. Instead, the focus for central banks is not an interest rate target, but rather an inflation target where interest rates 
are defined by the expected inflation rate. Even there is no general theory in determining exchange rates, it has been accepted that parity conditions, political risks, and Foreign Direct Investment (FDI), do affect exchange rates. Apart from the fact that no pattern has been appropriate in forecasting the behavior of exchange rates in the short - run, there are some concept that have an important role in determining the behavior of exchange rates in the long - run, such as the efficient market hypothesis. Thus, only unpredicted developments may give rise to fluctuations in the exchange rates.

\section{References}

Gujarati, Damodar N. "Basic Econometric". 2nd Edition, McGraw-Hill Book Company Siti Utami, Eno Inanga "Exchange Rates, Interest Rates, and Inflation Rates: The IFE Theory" Yan Peng, "Monetary Policy in China: The Fisher effect" Chaofan Chen, "Fisher Effect Theory and Fisher Paradox in China's Economy", October 2015 Abdulnasser Hatemi-J (UAE), "The International Fisher Effect: theory and application" Arusha Cooray: "The Fisher Effect: A Review of the Literature"

Mark C. Freeman, Ben Groom, Ekaterini Panopoulou and Theologos Pantelidis "Declining discount rates and the Fisher Effect: Inflated past, discounted future?"

Andreas Beyer, Alfred A. Haug and William G. Dewald, "Structural Breaks, Cointegration and Fisher Effect"

Emil Sundqvist, "An Empirical Investigation of the International Fisher Effect" 